\title{
UTILIZATION OF NATURAL RESOURCES AND SOCIAL SECURITY IN FISHERMEN FAMILIES ON SALEMO ISLAND AND WEST RANGAS, SOUTH SULAWESI PROVINCE
}

\author{
Hasbi $^{1^{*}}$, Mahmud Tang ${ }^{2}$, Mohamad Fauzi Sukimi ${ }^{3}$, Aryo Dwi Wibowo ${ }^{4}$, Yusriadi $^{5}$ \\ ${ }^{1,2}$ Associate Professor, Universitas Hasanuddin, Makassar, Indonesia; ${ }^{3}$ Professor, National University of Malaysia, \\ Malaysia; ${ }^{4}$ Ph.D. Candidate, Universitas Negeri Makassar, Makassar, Indonesia; ${ }^{5}$ Assistant Professor, Sekolah Tinggi \\ Ilmu Administrasi Puangrimaggalatung, Makassar, Indonesia. \\ Email: ${ }^{*}$ adhybachtiar29@gmail.com, ${ }^{2}$ amirmisnawati@gmail.com, ${ }^{3}$ misnawati_amir@yahoo.com, \\ ${ }^{4}$ andri.adw.wibowo@gmail.com, ${ }^{5}$ yayasanaladiyat@yahoo.co.id
}

Article History: Received on $14^{\text {th }}$ January 2020, Revised on $29^{\text {th }}$ March 2020, Published on $29^{\text {th }}$ April 2020

\begin{abstract}
Purpose of the study: This study aims to reveal the social security of traditional fishers in Salemo Island and West Rangas, South Sulawesi Province.

Methodology: The research method used is descriptive qualitative with a type of case study research. The research location was determined purposively, namely on Salemo Island, and West Rangas. Informants chose purposively, those who deserve used as sources of information. Data collection by in-depth interviews and observations, collect community ideas collectively with a Group Discussion Forum. Data collected and then reduced to the main findings following the focus of research.

Main Findings: The utilization of income for social security's is done by helping small fishers by providing loans for money to buy the equipment needed, among other anglers, borrowing mechanisms, especially fishermen who open businesses selling goods for daily necessities. Social securities are still running, such as fishers get a lot of results from the sea handing out their fish.
\end{abstract}

Applications of this study: The implications of this research can be a social function in overcoming the basic needs of community members to be used as a strengthening of the nation's character. Salemo Island fishers traditionally use local assets to use the environmentally friendly fishing gear as a form of local cultural wisdom of coastal communities.

Novelty/Originality of this study: The use of environmentally friendly fishing gear by Salemo Island fishers needs to be used as a model to be applied to other fishing communities, to avoid using explosives (fish bombs, anesthesia, and trawl) to catch fish.

Keywords: Social Security, Natural Resources, Fisher's, Family, Traditional, Indonesia.

\section{INTRODUCTION}

In history, humans have always struggled to meet basic needs in their lives (Ruparanganda, Ruparanganda, \& Mupfanochiya, 2017). According to the Central Statistics Agency (Statistik, 2017), as of March 2017, the number of poor people in Indonesia reached 27.77 million people or about 10.64 percent. Specifically, in South Sulawesi, the number of poor people from September 2017 amounted to 825,970 people (9.48 percent). In coastal areas, poverty is identical to small fishers, except fish traders and traders have better lives. On the island of Salemo in the Pangkep Regency, there is 85 percent of poor fishing families, while in the West Rangas neighborhood in Majene Regency, there is 80 percent (Purnamasari, 2011). The misery of small fishers is exacerbated by the use of marine resources by great anglers using non-environmentally friendly fishing gear such as the use of trawlers since the 1980s ((Sutrisno, 2014),(Lasri, Dewi, \& Prihatiningtyas, 2016), (Sulistiyono, 2014)). Fish bombs are increasingly being used, with 60 percent of Makassar City residents (Bachtiar, Setiawan, \& Sunarto, 2003). The results of Hasbi (2019) found the practice of securities in the fishing community on the island of Salemo applies the principle of reciprocity (situlung-tulung), loving one another (sipammase-mase), appropriateness (assitinajang), and visiting each other (silokkai) (Hasbi, 2019).

10,600 Indonesian fishermen should receive individual attention from the government, due to the condition of the fishing population in the village, which is still relatively weak and apprehensive. As a developing country, Indonesia's economic growth characterized by the process of ongoing differentiation and redistribution. The direction of growth occurs from the rich, not the poor, as predicted by trickle-down theory. This condition requires an in-depth study of the social security implications of poor fishing families. The problem is how the utilization of natural resource potential can be accessed for fishing communities. This study also illustrates the system of utilizing the potential of natural resources by fishers to overcome poverty.

This research stems from the assumption that human, natural, and social resources interrelated with one another through a series of cultural meanings and social relations. Society constructs elements of the world in various categories of natural resources through cognitive and normative categories, institutional relationships, and social practices by trying to control, exploit, and protect these resources. 
In this study, social security seen as an analytical concept concerning certain social functions. The term social security used for social problems. In broad terms, social security can refer to the efforts of individuals, social groups, families, the private sector, and government institutions. To address the basic needs of society, such as food, clothing, housing, health services, education, and clean water to meet living standards following community norms. Traditional social securities are social security whose sources are from outside government institutions that have traditionally received from social interactions such as kinship, friendship, patron-client relations.

Fisher's community relations always based on the local socio-cultural system. In general, the relationship between fishers is not only emphasized on the economic aspects of the employment relationship but also highlighted the principle of togetherness in the village community. Income and sources of livelihood are essential aspects of household life because income determines the ability of households to meet their needs. Household income is the income received by the house from the head of the family and the income of family members (Ngadi, 2016).

Fishers in doing business are looking for fish always to maintain good relations with the surrounding community. From the beginning until now, life-related to anglers is a matter of endless conversation. Even seminars are often held to discuss issues or life of fishers but only limited to workshops. No model can resolve fishermen's problems holistically, mainly traditional fishers.

This article expected to contribute to improving the welfare of the fishing community in Indonesia, mainly to strengthen social and cultural potential (traditional social securities). Including the value system, cooperation, kinship, solidarity, social attitude, responsibility, community, social gathering, and others.

\section{LITERATURE REVIEW}

\section{Natural Resources in Indonesia}

Indonesia is the largest archipelago country in the world, consisting of 5 large islands and 30 small islands, the total number of recorded 17,504 islands, 8,651 islands have named, 8,853 islands have not called, and 9,842 islands have verified (Retnowati, 2011). The location of Indonesia is also very strategic, which is located around the equator and between two oceans, namely the Indian Ocean and the Pacific Ocean. Therefore Indonesia has the highest richness of marine biodiversity or mega diversity in the world (Rilus, 2007).

The seas in Indonesia's territory are rich in various types of abundant fish. The potential of fish in the Indonesian sea can penetrate 6 million tons per year. These potential ranks were fourth in 2009 (Robi'In, 2008). Along this coastline, there are relatively narrow coastal areas, but they have potential biological and non-biological natural resources, artificial resources, and environmental services that are important for people's lives (Baransano \& Mangimbulude, 2011).

Coastal and marine resources are significant potentials in future development. Indonesia's sea area is 62 percent of the public sector, not including the exclusive economic zone of 2.7 million square kilometers. The vast Indonesian sea with abundant resources, if utilized for development, is right, predicted that development in Indonesia would progress rapidly (Ibrahim, 2014). The utilization of aquatic resources in Indonesia is basically to improve the lives of humankind in a better direction, primarily social, economic, and cultural growth (Rahardjo, 2012).

\section{Fishers in Indonesia}

Fishers in the Indonesian Encyclopaedia declared as people who actively engage in fishing, both directly and indirectly, as livelihoods. Fishermen with a broader sense, namely the fishing community, do not mean that those who manage their lives only look for fish in the sea to support their families but also those who are internally in the environment (Akbar, 2017). Fishers are a community that depends on their lives on marine resources (Iriani, 2019).

Fisher around the world seems to fit within four principal categories, based on the nature of, and background to, their particular fishing activities: Subsistence fishers: those catching fish as their source of food; Native aboriginal fisher: those belonging to aboriginal groups, often fishing for subsistence; Recreational fisher: those catching fish principally for their enjoyment; Commercial fisher: those catching fish for sale in domestic or export markets, these fishers are traditionally viewed as falling into artisanal and industrial category.

Fishers or groups of fishermen under Law Number 9 of 1985 are individuals or legal entities that carry out fisheries business, which includes, catch, breed, fresh or preserve fish for commercial purposes (Syafrini, 2014). The classification of fishers based on working groups includes individual fishers, fishermen of joint business groups, corporate fishermen (Irawati, 2011).

Based on data from the 2013 National Social and Economic Survey, it is known that 2.2 percent of households in Indonesia work as fishermen. The number is around 1.4 million fishermen household heads, the average number of household members in Indonesia is around four people, which means there are around 5.6 million Indonesians whose livelihoods depend on the heads of households who work as fishermen (Annisa, Satria, \& Kinseng, 2009). The fishing community categorized as a poor community with an indication that the level of the economy is still weak due to lowincome levels, low quality of life, little social welfare, and lives in trouble (Anugerah, Nurani, \& Sondita, 2016). 
Poverty in coastal communities is multidimensional and caused by not fulfilling the fundamental rights of the city including the need for food, health, education, employment, infrastructure (Imron, 2013). Besides the lack of business opportunities, lack of access to information technology and capital, culture, and lifestyles that tend to be wasteful, causing the poor people's bargaining position increasingly weak. At the same time, government policies have so far not favored the coastal communities as one of the stakeholders in the coastal area (Widodo, 2009).

\section{Social Security}

In the social work literature, social security is one type of social policy to overcome poverty and inequality in society (Harini, 2012). Each country has different definitions, systems, and approaches for dealing with poverty and inequality, and therefore, has changed social security systems and strategies (Rahim \& Hastuti, 2017). Social Security generally implemented in various forms of direct income allowances that are strictly related to taxation and income-maintenance policies (Zebua, Wildani, Lasefa, \& Rahmad, 2017). Social security often includes various schemes to increase access to essential social services, such as health care, education, and housing (Wantah, 2017).

Social securities can be referred to various businesses of individuals, groups, families, private and government institutions to address multiple basic living needs of community members such as adequate food, housing, education, health services, clean water, and so on (Nugraha, 2019). The traditional social securities are social security whose sources are from outside government institutions that have traditionally been given or received from social relations such as relatives, neighbours, people in the same village, friends, patron-clients (Tang, 2017). Thus, the term social security can use to refer to social phenomena at various levels ((Nadjib, 2013), (Sinaga, Widiono, \& Irnad, 2015), (Syator, 2014)).

\section{METHODOLOGY}

The research method used is descriptive qualitative with a type of case study research. The research location was determined purposively, namely on Salemo Island, Pangkajene Regency. This location chose with information obtained from 85 percent of the population of poor fishing families. The second location is the West Rangasneighborhood of Majene Regency; this second location also inhabited by 80 percent of poor category fishermen.

Informants chose purposively, those who deserve used as sources of information. First, the key informants were selected, namely the village head and subsequently appointed their citizens who were eligible to be expert informants and ordinary informants in the two locations. Interviews also conducted with expert informants from the Bugis-Makassar and Mandar tribes.

Data collection by in-depth interviews and observations, collect community ideas collectively with a Group Discussion Forum. Data collected and then reduced to the main findings following the focus of research. Then the data is presented in narrative form, and the last activity carried out by concluding. Components of data analysis include data collection, data reduction, data presentation, and completing an interactive series carried out continuously until accurate conclusions reached.

\section{RESULTS AND DISCUSSION}

\section{Natural Resource Utilization System in the Salemo Island Fishing Community}

\section{Crab Catching System}

Crab catchers (pabbukkang) use different equipment according to their rational choices. At first, they used nets (pukaq). Crab nets (pukaq) still used today. Crab nets use a count set (uteq). In the experience of fishers that crab nets are very easy to tear. Each crab that netted has the potential to tear the net by biting so that one crab can make tear from one to two holes.

A torn net, giving luck to others patching a torn net, on the island of Salemo only five people sew the nets. The cost of repairing the nets is eight thousand rupiahs. Some fishermen look for crabs at night using gas lamps (passulobukkang). These fishermen generally use a small boat (lepa-lepa) which used for rowing, but now uses a small engine. Fishers initially used spears to catch crabs, with crab spears dead and difficult to sell. Finally, fishers switch to using nets.

In the west season (December-March), fishers get a fortune because crabs come out of the mud during big waves. But if the waves are too big, the fishermen are afraid to come out so that they go out once for three days.In the western season, the fishing operation area looks for crabs only around the island of Salemo. In contrast, in the east season (AprilNovember), fishers can go further to catch crabs.

Catching crabs by fishers with nets is usually together with children or close relatives because fishers need two workers. Therefore, the children often late to school if they help their parents catch crabs. Crabs caught, and then sold to collectors. The sale crabs some used to pay debts in installments. The level of production and income of crab seeker fishers (pabbukang) is relatively low in the east season, only able to produce $3-5 \mathrm{~kg}$ of crabs (sixty thousand rupiahs to one hundred thousand rupiahs) a day. Their income will increase in the west season, between one hundred thousand rupiahs to two hundred thousand rupiahs per day (Helmi \& Satria, 2012). 


\section{Fishing System}

Fishers catch fish (pabbale) using various types of fishing gear according to the kind of fish. On the island of Salemo, fishers still use the net to catch fish, how to operate it by being pulled onto a boat when going to collect the fish. Other equipment is a fishing line by using 300 hooks for one fishing line. On the island of Salemo there are two fishermen using fishing rods. In the east season, about ten years ago, fishers could get a lot of fish catch. Whereas at present, fishers are having difficulty catching a lot of fish catches, because the fish population is decreasing. In the western season, fishers find it challenging to go to sea because the waves are big, so the location of catching fish is only around the island of Salemo. In certain areas, crab fishers also have an interest in agreeing (local rules) regarding the division of the sea area between fishers and crab fishermen (Syam, Suwarso, \& Purnamaningtyas, 2011).

\section{Utilization of Catches}

In general, fish catchers separate catch for consumption. Crab fishers rarely consume their catch. Allowance for a portion of revenue for daily operating expenses is an essential requirement that must always be available. Every day, fishers spend around fifty thousand rupiahs to seventy thousand rupiahs to buy fuel and smoke.

A fisher who has a debt must set aside a portion of his income to pay the debt (Therik, 2008). The condition of fishermen's houses on Salemo Island, on average, is better than fishing houses in other places, part of the income is used for housing improvements. Health maintenance funds for minor illnesses do not become a problem for fishers because they get free treatment from the community health center. But what often complained about is the cost of giving birth is very high, the problem overcome by the functioning of traditional social security mechanisms in the form of donations from family and neighbours.

Funds to meet the need for clean water have never been complained of by fishermen on Salemo Island. Generally, they can access from fellow fishers who invest a portion of their income into the water pumping machine. They can get clean water by paying 10.000 to 20.000 rupiahs. For bathing and washing water, they can get it from their well or neighbors for free. Funds for electricity needs range from 20.000 to 50.000 rupiahs.

While poor fishermen families, widows, elderly can access from neighbours for free with a maximum of 10 watts. Among fishers, their funds needed to fulfill social and religious needs, such as donations for places of worship between 20.000 to 50,000 rupiahs for families of able fishermen, and a minimum of 5,000 rupiahs for poor fishers per month. The closest relatives or neighbours, the higher the number of funds must be donated. For example, for families and distant neighbors, 30,000 rupiah is enough. Still, for families and close neighbours, a minimum of 50,000 rupiahs, close relatives, and neighbours are also assisted in the form of rice.

\section{Use of income as a traditional social security}

In addition to utilizing income for their own needs, Salemo Island fishers use part of their income for traditional social security; in this context, rich fishers help dozens of poor fishers on Salemo Island and also fishers from other islands. Wealthy fishers use part of their business to help dozens of fishers by providing capital to buy equipment. Wealthy fishers on Salemo Island give alms in the form of clothing to family members and neighbours who are lacking in the month of Ramadan, distributing clothes, gloves, especially for widows and parents.

\section{Natural Resource Utilization System in the West Rangas Fishing Community}

\section{Fishing System}

The season is very influential in the frequency and intensity of fishing. In general, the season divided into 2 , namely the west season and east season. Fishing gear used namely bombs, anesthetists, trawlers, and fishing rods. In the western season, the fishing gear used is bombs and anesthetics, West Rangas fishers operating far from their hometown. This bomb and anesthetic arrest activity carried out for approximately four months. They left their hometowns because the west season was marked by strong winds, rain, massive waves that did not allow them to make arrests around West Rangas. In the east season, fish trawlers and fishing rods generally used. This activity also lasts for four months. West Rangas fishers anesthetize and catch fish and must be in living conditions and not disabled. While fish caught by fishermen with fish bombs are all kinds of fish that live on coral reefs (Pontoh, 2011).

The level of production and income of West Rangas fishers is relatively high because it has abundant natural resources and fishing techniques. In West Rangas, there are four fishing techniques. In the western season, fishers search for fish using anesthesia techniques and fish bombs, there are also fishing with trawlers. In the eastern season, they hunt for fish with trawlers and fishing. Also, mothers and children in the east season look for shells in the sea. Fishers can earn hundreds of thousands per day. If the fishing season, fishers can earn 50,000 to 100,000 rupiah per day, they can earn between 2,000,000 to 3,000,000 rupiah per month. One of the things that benefit fishers is that the yield distribution is good enough. Equitable distribution-based principle "sangingmalupu" means work together so that their parts are the same. 


\section{Utilization of catches}

The income of fishers has significantly increased by fishing every night, ranging from 150,000 to 250,000 rupiah per night. Considerable income still felt to have not been able to improve their welfare (M.Yafiz, Sondita, Soemakaryo, \& Monintja, 2009). They are satisfied if every time they want to buy something, whether it is food or drink, clothing, twowheeled vehicles, the latest electronic devices, money is available so that almost all of the income spent on those needs. They have the term that money is easy to get, but it also runs out quickly even though it is not a basic need.

\section{Use of income as traditional social security}

In the lean season, fishers get help to meet their food and other needs. Sources of assistance are courtier, mixed sellers, and close relatives. Courtier is the first person visited to ask for help in the form of money loans. The loan limit is usually around 50,000 to 100,000 rupiah, enough for a day's needs. The maximum debt to the courtier is 500,000 rupiah. They are ashamed to borrow if it exceeds this amount. The debt will be paid after obtaining the catch. Fishers also usually acquire food from mixed sellers. Another alternative to be a source of help is the closest family, but this rarely happens. They used to borrow rice or money for daily needs.

During the western season, fishermen catches are very abundant (Kekenusa, 2006). Children and parents can ask fish from fishers. Usually, each person asks for fish, will be given about two to 20 head, depending on the catch. If the peak season of fish, according to one informant, can request fish for free ten times a day. Funds for death ceremonies such as money and food when a citizen dies much help the bereaved family. Almost all families come to help by bringing food and money. Some also bring rice, flour, and sugar, while cash, at least 5000 rupiahs per person.

During the holidays, many wealthy fishers in West Rangas provide clothing such as sarong. Usually, the giver and recipient have a close relationship or acquaintance. This habit of giving has become a tradition. It is also usual to give money as much as 20,000 to 50,000 rupiah for parents, while for children, usually 1,000 to 5,000 rupiah per person.

\section{CONCLUSION}

The utilization of natural resources in the fishing communities of Salemo and West Rangas can be seen in the use of different fishing gear. The catches and the sale proceeds used for various purposes. Fishers on Salemo Island use nets to catch fish and crabs, while fishers in West Rangas use nets, fishing rods, bombs, and anesthesia. The fishing communities in the two locations each respond differently to seasonal changes. Fishers on Salemo Island do not migrate and also do not change their fishing gear, but only look at the weather conditions. While fishers in West Rangas partly migrated to other islands using bombs and anesthetics, after entering the eastern season, they returned to West Rangas.

Utilization of catches by the two fishing communities is as follows: if they get a decent income, then they pay their debts to the retainer who is usually paid in installments and also their obligation to the stall manager. The use of other primary income is to fulfill daily basic needs. West Rangas fishers who earn more than Salemo Island fishers tend to be more consumptive. West Rangas fishers buy motor vehicles on average in installments, and the habit of buying food becomes more prominent than that of Salemo Island fishers.

The similarity between the two fishermen communities is the use of their income to fund life cycle ceremonies in their communities. They have in stock in preparing and spending more money on consumption in the month of Ramadan, the feast. Utilization of income for social security's such as large fishermen (retainer) on Salemo Island utilizes their income to help small fishers by buying necessary fishing equipment or lending money to purchase needed equipment. Among fishers, there are lending and borrowing mechanisms, especially between fishers who open businesses. Other fishers came to borrow various basic needs, such as rice, sugar, and cigarettes.

In daily life, giving and receiving as a social security mechanism still operate in these two communities, such as fishermen who earn a lot, distributing fish to poor people. This kind of gift is more prominent in West Rangas because its natural resources are more potential than Salemo Island. Likewise, the mechanism for granting access to take fish is to be sold by widows and to be eaten for parents.

\section{LIMITATION AND STUDY FORWARD}

The use of fishing gear that is environmentally friendly by Salemo Island fishers needs using as a model applied to other fishing communities. Especially on other islands that use explosives (fish bombs, anesthesia, and trawl) and also for fishers in other places such as West Rangas fishermen.

In this study only looks at the lives of the two fishing communities, so for further research, it is necessary to look at the role of the government in providing capital loans with security procedures and low-interest rates so that small fishers do not depend on large fishers. The two fishing communities need help in processing fish technology to improve the quality of fish and fish processing products, especially for mothers to increase the role of women in increasing family income, especially on Salemo Island. Alternative livelihoods are also needed for fishers on Salemo Island during the western season. In the economical use of fishermen's income, counselling is required to fishermen wives so that their family income can improve their welfare without neglecting their social and religious obligations. 


\section{AUTHORS CONTRIBUTION}

The contributions of the first author and second author are involved in planning and supervising work, data analysis, and interpretation of research results. The third, fourth, and fifth authors are engaged in processing works, composing manuscripts, collecting data, and designing numbers and tables.

\section{REFERENCES}

1. Akbar, T. (2017). Nelayan, Lingkungan, Dan Perubahan Iklim (Studi Terhadap Kondisi Sosial Ekonomi Pesisir Di Kabupaten Malang). Wahana, 68(1).

2. Annisa, L., Satria, A., \& Kinseng, R. A. (2009). Konflik Nelayan Di Jawa Timur: Studi Kasus Perubahan Struktur Agraria dan Diferensiasi Kesejahteraan Komunitas Pekebun di Lebak, Banten. Sodality Jurnal Sosiologi Pedesaan, 3(1). https://doi.org/10.22500/sodality.v3i1.5870

3. Anugerah, Y., Nurani, T. W., \& Sondita, M. F. A. (2016). Kompetensi Nelayan Rawai Tuna Ditinjau Dari Standar Kompetensi Kerja Nasional Indonesia (Skkni) Di Ppn Palabuhanratu. Jurnal Sosial Ekonomi Kelautan Dan Perikanan, 11(2). https://doi.org/10.15578/jsekp.v11i2.3693

4. Bachtiar, S. ., Setiawan, B., \& Sunarto, S. (2003). Fisherman Perception and Behavior of Marine Resources Exploitation in Kodingareng Island, South Sulawesi. Jurnal Manusia Dan Lingkungan, 10(3).

5. Baransano, H. K., \& Mangimbulude, J. C. (2011). Eksploitasi dan Konservasi Sumberdaya Hayati Laut dan Pesisir di Indonesia. Jurnal Biologi Papua, 3(1).

6. Harini, N. D. (2012). Dari Miyang Ke Longlenan: Pengaruh Jaringan Sosial Pada Transformasi Masyarakat Nelayan. International Journal of Indonesia Society and Culture, 4(2). https://doi.org/10.15294/komunitas.v4i2.2413

7. Hasbi. (2019). Sekuritas Sosial Perempuan Rawan Sosial Ekonomi Pada Komunitas Nelayan Pulau Kecil (Kasus Pulau Salemo, Desa Mattiro Bombang, Kecamatan Liukang, Kabupaten Pangkajene Kepulauan, Sulawesi Selatan). Jurnal Penelitian Kesejahteraan Sosial, 18(1). Retrieved from https://ejournal.kemsos.go.id/index.php/jpks/article/view/1639

8. Helmi, A., \& Satria, A. (2012). Strategi Adaptasi Nelayan terhadap Perubahan Ekologis. Makara, Sosial Humaniora, 16(1), 68-78. https://doi.org/10.7454/mssh.v16i1.1494

9. Ibrahim, Y. (2014). Kontribusi Sektor Pariwisata Terhadap Gdp Indonesia Tahun 2004 - 2009. Economics Development Analysis Journal, 3(2).

10. Imron, M. (2013). Kemiskinan Dalam Masyarakat Nelayan. Junral Masyarakat Dan Budaya, 5(1).

11. Irawati, I. (2011). Tanggung Jawab Negara dalam Melindungi Hak Nelayan Tradisional Indonesia di Perairan Australia. Mimbar: Jurnal Sosial Dan Pembangunan, 27(1).

12. Iriani. (2019). Sekuritas Sosial Pada Nelayan Tradisional Di Penggoli Kota Palopo. Walasuji, 10(1). https://doi.org/10.36869/wjsb.v10i1.40

13. Kekenusa, J. S. (2006). Analisis Penentuan Musim Penangkapan Ikan Cakalang (Katsuwonus pelamis) Di Perairan Sekitar Bitung Sulawesi Utara. Jurnal Protein, 13(1). Retrieved from http://ejournal.umm.ac.id/index.php/protein/article/view/18

14. Lasri, L., Dewi, N., \& Prihatiningtyas, B. (2016). Pemberdayaan Pedagang Pasar Tradisional Blimbing Berbasis Partisipatif Dalam Perlindungan Sosial. Jurnal Ilmiah Ilmu Kesehatan, 4(3). https://doi.org/10.33366/cr.v4i3.439

15. M.Yafiz, Sondita, M. F. A., Soemakaryo, S., \& Monintja, D. R. (2009). Analisis Finansial Usaha Penangkapan Ikan dalam Model Perbaikan Kesejahteraan Nelayan di Kabupaten Rokan Hilir Provinsi Riau. Jurnal $\begin{array}{lllll}\text { Perikanan Dan } & \text { Kelautan, } & \text { 14(1), } & \text { Retrieved } & \text { from }\end{array}$ https://jpk.ejournal.unri.ac.id/index.php/JPK/article/view/16/15

16. Nadjib, M. (2013). Agama, Etika dan Etos Kerja dalam Aktivitas Ekonomi Masyarakat Nelayan Jawa. Jurnal Ekonomi Dan Pembangunan, 21(2).

17. Ngadi, N. (2016). Mata Pencaharian Dan Pendapatan Rumah Tangga Di Kawasan Pesisir Kabupaten Wakatobi. Jurnal Sosial Ekonomi Kelautan Dan Perikanan, 11(2). https://doi.org/10.15578/jsekp.v11i2.3696

18. Nugraha, P. (2019). Kesejahteraan Sosial Masyarakat terhadap Penggunaan Dana Desa di Desa Maleku. Walasuji, 1(2). https://doi.org/10.36869/wjsb.v10i2.7

19. Pontoh, O. (2011). Penangkapan Ikan Dengan Bom di Daerah Terumbu Karang Desa Arakan dan Wawontulap. Jurnal Perikanan Dan Kelautan Tropis, 7(1). https://doi.org/10.35800/jpkt.7.1.2011.17

20. Purnamasari, A. M. (2011). Pengembangan Masyarakat Untuk Pariwisata di Kampung Wisata Toddabojo Provinsi Sulawesi Selatan. Journal of Regional and City Planning, 22(1).

21. Rahardjo, W. (2012). Manajemen Tata Kelola Sumber Daya Alam Berbasis Paradigma Ekologi Politik. Politika: Jurnal Ilmu Politik, 3(2).

22. Rahim, A., \& Hastuti, D. R. D. (2017). Struktur Usaha Penangkapan Ikan Oleh Nelayan Tradisional Di Desa Pecangaan Kecamatan Batangan Kabupaten Pati. Jurnal Litbang, 13(2). https://doi.org/10.33658/j1.v13i2.96

23. Retnowati, E. (2011). Nelayan Indonesia Dalam Pusaran Kemiskinan Struktural (Perspektif Sosial, Ekonomi Dan Hukum). Perspektif, 16(3). https://doi.org/10.30742/perspektif.v16i3.79

24. Rilus, A. K. (2007). Konflik-Konflik Sumberdaya Alam di Kalangan Nelayan di Indonesia. Sodality: Jurnal 
Sosiologi Pedesaan, 1(1).

25. Robi'In, B. (2008). Sistem Informasi Geografis Sumber Daya Alam Indonesia Berbasis Web. Jurnal Informatika Ahmad Dahlan, 1(1).

26. Ruparanganda, L., Ruparanganda, B., \& Mupfanochiya, A. T. (2017). Traditional Social Security Systems in the face of Urbanization: Lessons from a Rural Community in Buhera District of Zimbabwe. International Journal of Humanities and Social Science, 7(2). Retrieved from http://www.ijhssnet.com/journal/index/3774

27. Sinaga, H., Widiono, S., \& Irnad. (2015). Pola Hubungan Patron- Klien Pada Komunitas Nelayan Di Kelurahan Malabro Kecamatan Teluk Segara Kota Bengkulu. Jurnal Agrisep, 14(2). https://doi.org/10.31186/jagrisep.14.2.167-176

28. Statistik, B. P. (2017). Indonesia Dalam Angka. Jakarta.

29. Sulistiyono, S. T. (2014). Mengenal Sistem Pengetahuan, Teknologi, dan Ekonomi Nelayan Pantai Utara Jawa. Jurnal Sejarah Dan Pembelajarannya, 4(2). https://doi.org/10.25273/ajsp.v4i02.825

30. Sutrisno, E. (2014). Implementasi Pengelolaan Sumber Daya Pesisir Berbasis Pengelolaan Wilayah Pesisir Secara Terpadu Untuk Kesejahteraan Nelayan (Studi Di Perdesaan Nelayan Cangkol Kelurahan Lemahwungkuk Kecamatan Lemahwungkuk Kota Cirebon). Jurnal Dinamika Hukum, 14(1).

31. Syafrini, D. (2014). Nelayan Vs Rentenir Studi Ketergantungan Nelayan Terhadap Rentenir Pada Masyarakat Pesisir. Jurnal Ilmu Sosial Mamangan, 3(2).

32. Syam, A. R., Suwarso, S., \& Purnamaningtyas, S. E. (2011). Laju Eksploitasi Kepiting Bakau (Scylla Serrata) di Perairan Mangrove Mayangan, Subang - Jawa Barat. Jurnal Penelitian Perikanan Indonesia, 17(3).

33. Syator, A. (2014). Ekologi Politik Masyarakat Pesisir (Analisis Sosiologis Kehidupan Sosial-Ekonomi Dan

34. Tang, M. (2017). Traditional Social Security in the Fisherman Communities in Small Islands and Coastal Region South Sulawesi. Proceedings of the Unhas International Conference on Social and Political Science (UICoSP 2017). https://doi.org/10.2991/uicosp-17.2017.19

35. Therik, W. M. A. (2008). Nelayan dalam Bayang Juragan Potret Kehidupan Nelayan Tradisional Bajo di Tanjung Pasir, Pulau Rote, Nusa Tenggara Timur. Jurnal Ekonomi Peluang, 2(1). Retrieved from http://ejurnal.ukim.ac.id/index.php/peluang/article/view/124

36. Wantah, E. (2017). Pemberdayaan Nelayan Berbasis Pendidikan Ekonomi dan Potensi Pesisir di Kabupaten Minahasa Utara. Jurnal Dan Teori Dan Praksis Pemblejaran IPS, 2(2). https://doi.org/10.17977/um022v2i22017p095

37. Widodo, S. (2009). Strategi Nafkah Rumah Tangga Nelayan dalam Menghadapi Kemiskinan. Jurnal Kelautan, $2(2)$.

38. Zebua, Y., Wildani, P. K., Lasefa, A., \& Rahmad, R. (2017). Faktor Penyebab Rendahnya Tingkat Kesejahteraan Nelayan Pesisir Pantai Sri Mersing Desa Kuala Lama Kabupaten Serdang Bedagai Sumatera Utara. Jurnal Geografi, 9(1). https://doi.org/10.24114/jg.v9i1.6923 